\title{
DNA binding, anti-tumour activity and reactivity toward cell thiols of acridin-9-ylalkenoic derivatives
}

\author{
O SALEM ${ }^{\mathrm{a}}$, M VILKOVA $^{\mathrm{b}}, \mathrm{J}_{\text {PLSIKOVA }}^{\mathrm{a}}$, A GROLMUSOVA $^{\mathrm{c}}$, M BURIKOVA $^{\mathrm{c}}$, \\ M PROKAIOVA $^{\mathrm{b}}, \mathrm{H}_{\text {PAULIKOVA }}^{\mathrm{c}}, \mathrm{J}_{\text {IMRICH }}^{\mathrm{b}}$ and M KOZURKOVA ${ }^{\mathrm{a}, *}$ \\ a Department of Biochemistry, P J Šafárik University in Kosice, Faculty of Science, Moyzesova 11, \\ SK-04001 Kosice \\ ${ }^{b}$ Department of Organic Chemistry, P J Šafárik University in Kosice, Faculty of Science, Moyzesova 11, \\ SK-04001 Kosice \\ ${ }^{\mathrm{c}}$ Department of Biochemistry and Microbiology, Faculty of Chemical and Food Technology, \\ Slovak Technical University, Radlinského 9, SK-81237 Bratislava, Slovak Republic \\ e-mail: maria.kozurkova@upjs.sk
}

MS received 10 October 2014; revised 15 January 2015; accepted 24 January 2015

\begin{abstract}
In this paper, we describe the synthesis, biochemical properties and biological activity of a series of new 9-substituted acridine derivatives with a reactive alkene moiety: 9-[(E)-2-phenylethenyl] acridine (1) and methyl (2E)-3-(acridin-9-yl)-prop-2-enoate (2). The interaction of derivatives $\mathbf{1}$ and $\mathbf{2}$ with calf thymus DNA was investigated using UV-Vis, fluorescence and circular dichroism spectroscopy. The binding constants $\mathrm{K}$ were estimated as being in the range of 1.9 to $7.1 \times 10^{5} \mathrm{M}^{-1}$, and the percentage of hypochromism was found to be $40-57 \%$ (from spectral titration). UV-Vis, fluorescence, and CD measurements indicate that the compounds were effective DNA-intercalating agents. Electrophoretic separation proved that ligands $\mathbf{1}$ and $\mathbf{2}$ relaxed topoisomerase I at a concentration of $5 \mu \mathrm{M}$. Ester 2 was shown to have a stronger cytostatic effect on leukemia cell line L1210 than alkene $\mathbf{1}$. The incubation of ligands $\mathbf{1}$ and $\mathbf{2}$ with the ovarian carcinoma cell line A2780 confirmed their extensive cytotoxic effects, an effect which was particularly pronounced in the case of ligand 2. Cytotoxicity tests against A2780 cells demonstrate that a conjugate of compound $\mathbf{2}$ with $L$-cysteine (3) is less cytotoxic than compound $\mathbf{2}$, especially at concentrations greater than $10 \mu \mathrm{M}$.
\end{abstract}

Keywords. DNA binding; anti-tumour activity; acridin-9-ylalkenoic derivatives, glutathione.

\section{Introduction}

Acridine is one of the most commonly used DNA intercalating scaffolds for anti-cancer, anti-viral, antimalarial, and anti-bacterial agents and has been the focus of extensive studies. ${ }^{1-4}$ DNA is generally the primary intracellular target of anti-cancer drugs, so any interaction between small molecules and DNA can cause DNA damage in cancer cells thereby inhibiting the growth of cancer and resulting in cell death or apoptosis. ${ }^{5-7}$ The intercalation of planar molecules between base pairs causes the DNA helix to extend and decreases its winding angle. The archetypal DNA-intercalating agents are 9-aminoacridine and its derivatives. These compounds bind reversibly to DNA by intercalation, but they do not usually interact with it covalently. The intercalation of the acridines is facilitated by cation formation and sufficient levels of molecular planarity. The 9-anilinoacridine derivative amsacrine

*For correspondence
( $m$-AMSA), 4'-(acridin-9-ylamino)-methanesulfon- $m$ anisidide, has been in clinical use since the 1970s. The effect of amsacrine and its second-generation analogues is closely associated with the ability of these DNA intercalators to interfere adversely with DNA strand cleavage. ${ }^{1,8}$ The cytotoxic effect of most acridine-based drugs is based on their ability to suppress topoisomerase activity. Some acridine derivatives can act as multitarget anti-cancer drugs. In addition to demonstrating a high affinity to DNA, acridine derivatives with reactivity towards thiols are able to modulate the level of cellular thiols. The reactivity of such substances with sulfhydryls can alter intracellular glutathione redox status (GSSG/GSH), which modulates a wide range of cellular events such as selective gene expression, DNA synthesis, and the regulation of the cell cycle Moreover a reduction in the GSH level decreases the detoxification potency of the cells and GSH depletion might trigger subsequent apoptosis by leaving the cells unprotected against the production of thiol oxidation radicals. ${ }^{9-11}$ 
In our previous work ${ }^{12}$ we studied new acridinethiazolidinone derivatives and their interactions with calf thymus DNA and HL60, L1210 and A2780 cell lines. All of the tested derivatives displayed strong cytotoxic activity in vitro. The cancer cells accumulated acridine derivatives very rapidly and changes in the glutathione level were confirmed. The compounds inhibited the proliferation of the cancer cells and induced an arrest in the cell cycle and cell death. Their influence on the cells was associated with their reactivity towards thiols and DNA binding activity.

In this paper we describe the synthesis, biochemical properties, and biological activity of novel 9-substituted acridine derivatives with a reactive alkene moiety: 9[(E)-2-phenylethenyl]acridine (1) and methyl (2E)-3(acridin-9-yl)-prop-2-enoate (2). These compounds may show potential as anti-cancer agents due to their sensitivity toward nucleophilic groups present in biomolecules. Our study focuses on the capability of both compounds to bind to DNA and interfere with human topoisomerase I, and also examines the in vitro antiproliferative activity of the derivatives against mouse lymphocytic leukemia cells (L1210) and human ovarian cancer cell lines (A2780). The high level of reactivity between the thiol group and the double bond is wellknown, and therefore the new derivatives were also tested for their ability to reduce the level of glutathione in cells. For this purpose, a conjugate of ester 2 with cysteine 3-\{[1-(acridin-9-yl)-3-methoxy-3-oxopropyl] sulphanyl $\}$-2-aminopropanoic acid $\mathbf{3}$ was prepared and the effect of the ester on cell viability was evaluated.

\section{Experimental}

\subsection{Materials and chemicals}

The studied analogues (table 1) were prepared prior to the experiment and were dissolved in DMSO to a final concentration of $2 \times 10^{4} \mu \mathrm{M}$. All chemicals and reagents were of reagent grade and were used without further purification. Propidium iodide (PI), Hoechst 33342 , ethidium bromide, Triton $\mathrm{X}-100$, reduced form of glutathione (GSH), 3-(4,5-dimethylthiazol-2-yl)-2,5diphenyl tetrazolium bromide (MTT), dimethyl sulfoxide
(DMSO, Serva), and calf thymus DNA were obtained from Sigma-Aldrich Chemie (Germany). EDTA, RNase $\mathrm{A}$, and proteinase $\mathrm{K}$ were purchased from Serva

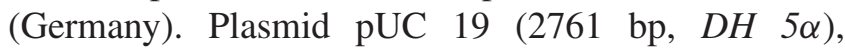
agarose (type II No-A-6877) (Sigma), 5,5'-dithio-bis(2nitrobenzoic acid) (DTNB) were obtained from Merck (Germany). All other chemicals were purchased from Lachema (Czech Republic).

\subsection{Chemistry}

2.2a Synthesis of 9-[(E)-2-phenylethenyl]acridine (trivial 9-(2-styryl)acridine) (1): Sodium hydride (60\% purity, $145 \mathrm{mg}, 3.63 \mathrm{mmol}$ ) was added to a solution of benzyltriphenyl-phosphonium chloride (1000 mg, $2.57 \mathrm{mmol}$ ) in anhydrous tetrahydrofuran $(5 \mathrm{~mL})$. The solution was cooled to $-10^{\circ} \mathrm{C}$ and stirred for $30 \mathrm{~min}$. An equimolar amount of acridin-9-carbaldehyde ${ }^{13}$ (500 mg, $2.41 \mathrm{mmol}$ ) was added and the solution was stirred for $1 \mathrm{~h}$ at $-10^{\circ} \mathrm{C}$. The resulting mixture was allowed to reach room temperature and the stirring was continued for $12 \mathrm{~h}$. The solvent was evaporated under reduced pressure and the residue was purified with column chromatography $\left(\mathrm{SiO}_{2}\right.$, 9:1 v/v cyclohexane/acetone) to produce derivative $\mathbf{1}$ as a pure $Z$ isomer.

Yield: $320 \mathrm{mg}(47 \%)$, M.p. $184-185^{\circ} \mathrm{C}$ (ethyl acetate). ${ }^{1} \mathrm{H}$ NMR $\left(400 \mathrm{MHz}, 25^{\circ} \mathrm{C}, \mathrm{CDCl}_{3}\right): \delta 8.32(\mathrm{dd}$, $\left.J=8.4,1.0 \mathrm{~Hz}, 2 \mathrm{H}, \mathrm{H}-1^{\prime}, 8^{\prime}\right), 8.25$ (br d, $J=8.4$ $\left.\mathrm{Hz}, 2 \mathrm{H}, \mathrm{H}-4^{\prime}, 5^{\prime}\right), 7.88$ (d, $\left.J=16.4 \mathrm{~Hz}, 1 \mathrm{H}, \mathrm{H}-\beta\right), 7.78$ (ddd, $\left.J=8.4,6.4,1.0 \mathrm{~Hz}, 2 \mathrm{H}, \mathrm{H}-3^{\prime}, 6^{\prime}\right), 7.68(\mathrm{dd}, J=$ 8.0, $1.6 \mathrm{~Hz}, 2 \mathrm{H}, \mathrm{H}-2^{\prime \prime}, 6^{\prime \prime}$ ), 7.51 (ddd, $J=8.4,6.4,0.8$ $\left.\mathrm{Hz}, 2 \mathrm{H}, \mathrm{H}-2^{\prime}, 7^{\prime}\right), 7.46$ (t, $\left.J=8.0 \mathrm{~Hz}, 2 \mathrm{H}, \mathrm{H}-3^{\prime \prime}, 5^{\prime \prime}\right)$, 7.40 (m, 1H, H-4"), 7.04 (d, $J=16.4 \mathrm{~Hz}, 1 \mathrm{H}, \mathrm{H}-\alpha$ ) ppm. ${ }^{13} \mathrm{C}$ NMR $\left(100 \mathrm{MHz}, 25^{\prime} \mathrm{C}, \mathrm{CDCl}_{3}\right): \delta 148.7(\mathrm{C}-$ $\left.4^{\prime} \mathrm{a}, 10^{\prime} \mathrm{a}\right), 143.2\left(\mathrm{C}^{\prime} 9^{\prime}\right), 139.5(\mathrm{C}-\alpha), 136.5\left(\mathrm{C}-1^{\prime \prime}\right), 130.0$ $\left(\mathrm{C}-3^{\prime}, 6^{\prime}\right), 129.9\left(\mathrm{C}-4^{\prime}, 5^{\prime}\right), 129.0\left(\mathrm{C}-3^{\prime \prime}, 5^{\prime \prime}\right), 128.8\left(\mathrm{C}-4^{\prime \prime}\right)$, $126.9\left(\mathrm{C}-2^{\prime \prime}, 6^{\prime \prime}\right), 125.9\left(\mathrm{C}-1^{\prime}, 8^{\prime}\right), 125.6\left(\mathrm{C}-2^{\prime}, 7^{\prime}\right), 124.5$ (C-8'a,9'a), 122.1 (C- $\beta)$ ppm. For $\mathrm{C}_{21} \mathrm{H}_{15} \mathrm{~N}$ (281.36): calcd. C 89.65, H 5.37, N 4.98; found C 89.48, H 5.44, $\mathrm{N} 4.83$.

2.2b Synthesis of methyl (2E)-3-(acridin-9-yl)-prop2-enoate (2): A mixture of methyl (triphenylphosphoranylidene)acetate (1.66 g, $4.96 \mathrm{mmol}$ ) and acridin-9-

Table 1. UV-Vis absorption data of acridine derivatives 1-3.

\begin{tabular}{lccccc}
\hline Ligand & $\begin{array}{c}\lambda_{\max } \text { free } \\
(\mathbf{n m})\end{array}$ & $\begin{array}{c}\lambda_{\max } \text { bound } \\
(\mathbf{n m})\end{array}$ & $\begin{array}{c}\Delta \boldsymbol{\lambda} \\
(\mathbf{n m})\end{array}$ & $\begin{array}{c}\boldsymbol{K} \\
{\left[\mathbf{M}^{-1}\right]}\end{array}$ & $\begin{array}{c}\text { Hypochromicity } \\
(\boldsymbol{\%})\end{array}$ \\
\hline $\mathbf{1}$ & 368 & 369 & 1 & $7.1 \times 10^{5}$ & 57 \\
$\mathbf{2}$ & 361 & 362 & 1 & $1.9 \times 10^{5}$ & 40 \\
$\mathbf{3}$ & 361 & 363 & 2 & $3.4 \times 10^{6}$ & 18 \\
\hline
\end{tabular}


carbaldehyde (1.0 g, $4.83 \mathrm{mmol})$ in dry chloroform $(5 \mathrm{~mL})$ was stirred overnight at room temperature. The solvent was evaporated under reduced pressure and the residue was purified with column chromatography $\left(\mathrm{SiO}_{2}, 9: 1 \mathrm{v} / \mathrm{v}\right.$ cyclohexane/acetone $)$ to produce derivative $\mathbf{2}$ as yellow needles of pure $Z$ isomer.

Yield: $570 \mathrm{mg}(45 \%)$, M.p. $150-152^{\circ} \mathrm{C}$ (ethyl acetate). ${ }^{1} \mathrm{H}$ NMR $\left(400 \mathrm{MHz}, 25^{\circ} \mathrm{C}, \mathrm{CDCl}_{3}\right): \delta 8.54$ $(\mathrm{d}, J=16.4 \mathrm{~Hz}, 1 \mathrm{H}, \mathrm{H}-\beta), 8.25$ (dd, $J=9.0,1.0$ $\left.\mathrm{Hz}, 2 \mathrm{H}, \mathrm{H}-4^{\prime}, 5^{\prime}\right), 8.17$ (dd, $J=8.4,1.0 \mathrm{~Hz}, 2 \mathrm{H}, \mathrm{H}-$ $\left.1^{\prime}, 8^{\prime}\right) 7.80\left(\mathrm{ddd}, J=9.0,6.6,1.0 \mathrm{~Hz}, 2 \mathrm{H}, \mathrm{H}-3^{\prime}, 6^{\prime}\right)$, 7.56 (ddd, $\left.J=8.4,6.6,1.0 \mathrm{~Hz}, 2 \mathrm{H}, \mathrm{H}-2^{\prime}, 7^{\prime}\right), 6.48$ (d, $J=16.4 \mathrm{~Hz}, 1 \mathrm{H}, \mathrm{H}-\alpha), 3.93\left(\mathrm{~s}, 3 \mathrm{H}, \mathrm{CH}_{3}\right) \mathrm{ppm} .{ }^{13} \mathrm{C}$ NMR $\left(100 \mathrm{MHz}, 25^{\circ} \mathrm{C}, \mathrm{CDCl}_{3}\right): \delta=166.3(\mathrm{C}=\mathrm{O})$, 148.8 (C-4'a,10'a), 139.7 (C- $\beta), 139.6$ (C-9'), 130.4 $\left(\mathrm{C}-4^{\prime}, 5^{\prime}\right), 130.0\left(\mathrm{C}-3^{\prime}, 6^{\prime}\right), 129.1(\mathrm{C}-\alpha), 126.7\left(\mathrm{C}-2^{\prime}, 7^{\prime}\right)$, $125.4\left(\mathrm{C}-1^{\prime}, 8^{\prime}\right), 124.0\left(\mathrm{C}^{\prime} 8^{\prime} \mathrm{a}, 9^{\prime} \mathrm{a}\right), 52.4\left(\mathrm{CH}_{3}\right) \mathrm{ppm}$. For $\mathrm{C}_{17} \mathrm{H}_{13} \mathrm{NO}_{2}$ (263.30): calcd. C 77.55, H 4.98, N 5.32; found C 77.33, H 4.82, N 5.21.

2.2c Synthesis of conjugate 3-\{[1-(acridin-9-yl)-3methoxy-3-oxopropyl]sulfanyl\}-2-aminopropanoic acid (3): A methanolic solution $(0.5 \mathrm{~mL})$ of derivative 2 (0.02 g, $0.076 \mathrm{mmol}, 1.0$ equiv.) was added dropwise to a stirred solution of $L$-cystein $(0.02 \mathrm{~g}, 0.114 \mathrm{mmol}, 1.5$ equiv.) in a mixture of methanol $(1.5 \mathrm{~mL})$ and Tris. $\mathrm{HCl}$ $(\mathrm{pH}=7.4,1 \mathrm{~mL})$. The reaction mixture was stirred at room temperature for ca. $1 \mathrm{~h}$ until the initial quantity of derivative $\mathbf{2}$ had disappeared (TLC). The precipitate which had formed was filtered off and washed with dry methanol.

Yield: $15 \mathrm{mg}$ (52\%), M.p. $188-190^{\circ} \mathrm{C} .{ }^{1} \mathrm{H}$ NMR (600 $\left.\mathrm{MHz}, \mathrm{DMSO}-D_{6}, 25^{\circ} \mathrm{C}\right): \delta 8.37(\mathrm{dd}, J=9.0,1.2 \mathrm{~Hz}$, $\left.2 \mathrm{H}, \mathrm{H}-1^{\prime}, 8^{\prime}\right), 8.14\left(\mathrm{dd}, J=9.0,1.2 \mathrm{~Hz}, 2 \mathrm{H}, \mathrm{H}-4^{\prime}, 5^{\prime}\right)$, 7.84 (ddd, $J=9.0,6.6,1.2 \mathrm{~Hz}, 2 \mathrm{H}, \mathrm{H}-3^{\prime}, 6^{\prime}$ ), 7.66 (ddd, $\left.J=9.0,6.6,1.2 \mathrm{~Hz}, 2 \mathrm{H}, \mathrm{H}-2^{\prime}, 7^{\prime}\right), 4.27(\mathrm{dd}, J=14.4$, $\left.9.0 \mathrm{~Hz}, 1 \mathrm{H}, \mathrm{COCH}_{\mathrm{a}}\right), 4.08(\mathrm{dd}, 1 \mathrm{H}, J=14.4,6.6 \mathrm{~Hz}$, $\left.1 \mathrm{H}, \mathrm{COCH}_{\mathrm{b}}\right), 4.01(\mathrm{dd}, J=9.0,6.6 \mathrm{~Hz}, 1 \mathrm{H}, \mathrm{SCH}), 3.97$ $(\mathrm{m}, 1 \mathrm{H}, \mathrm{NCH}), 3.38\left(\mathrm{~s}, 3 \mathrm{H}, \mathrm{OCH}_{3}\right), 3.08(\mathrm{~d}, J=5.4$ $\left.\mathrm{Hz}, 2 \mathrm{H}, \mathrm{SCH}_{2}\right) \mathrm{ppm} .{ }^{13} \mathrm{C} \mathrm{NMR}\left(150 \mathrm{MHz}, \mathrm{DMSO}-D_{6}\right.$, $\left.25^{\circ} \mathrm{C}\right): \delta 171.5\left(\mathrm{COOCH}_{3}\right), 169.5(\underline{\mathrm{COOH}}), 148.5(\mathrm{C}-$ $\left.4^{\prime} \mathrm{a}, 10^{\prime} \mathrm{a}\right), 141.7\left(\mathrm{C}-9^{\prime}\right), 130.6\left(\mathrm{C}-3^{\prime}, 6^{\prime}\right), 130.3\left(\mathrm{C}-4^{\prime}, 5^{\prime}\right)$, $126.7\left(\mathrm{C}-2^{\prime}, 7^{\prime}\right), 125.3\left(\mathrm{C}-1^{\prime}, 8^{\prime}\right), 125.1\left(\mathrm{C}-8^{\prime} \mathrm{a}, 9^{\prime} \mathrm{a}\right), 52.7$ $\left(\mathrm{OCH}_{3}\right), 52.4(\mathrm{NCH}), 48.1(\mathrm{SCH}), 31.8\left(\mathrm{SCH}_{2}\right), 29.5$ (C-CO) ppm.

\subsection{Biological activity}

2.3a Spectral and DNA binding studies: UV-vis spectra were measured on a Varian Cary 100 UV-Vis spectrophotometer in $0.01 \mathrm{M}$ Tris- $\mathrm{HCl}$ buffer $(\mathrm{pH}=$ 7.3). The solution of calf thymus DNA (ctDNA) in TE buffer was sonicated for 5 min and the DNA concentration was determined from its absorbance at $260 \mathrm{~nm}$. The purity of DNA was determined by monitoring the value $A_{260} / A_{280}$. DNA concentration measured at $260 \mathrm{~nm}$ and expressed as micromolar equivalents of the base pairs ranging from 0 to $110 \mu \mathrm{M}$ bp for 9-[(E)-2-phenylethenyl]acridine (1) and from 0 to $95 \mu \mathrm{M}$ bp for methyl (2E)-3-(acridin-9-yl)-prop-2-enoate (2) and 3-\{[1-(acridin9-yl)-3-methoxy-3-oxopropyl]sulfanyl \}-2-aminopropanoic acid (3). The derivatives 1-3 were dissolved in DMSO, from which working solutions were prepared through dilution to a concentration of $25 \mu \mathrm{M}$ using a $0.01 \mathrm{M}$ Tris- $\mathrm{HCl}$ buffer. All measurements were performed at $24^{\circ} \mathrm{C}$.

2.3b Equilibrium binding titration: The binding affinities were calculated from absorbance spectra according to the method of McGhee and von Hippel using data points from a Scatchard plot. ${ }^{14}$ The binding data were fitted using GNU Octave 2.1.73 software. ${ }^{15}$

\section{3c Fluorescence measurements: Fluorescence} measurements of free derivatives $\mathbf{1}$ and $\mathbf{2}$ were performed on a Varian Cary Eclipse spectrofluorimeter with a $5 \mathrm{~nm}$ slit width for excitation and emission beams at a concentration of $20 \mu \mathrm{M}$ in a $0.01 \mathrm{M}$ Tris $-\mathrm{HCl}$ buffer at $\mathrm{pH}=7.4$. Emission spectra were recorded in the region of 400-700 $\mathrm{nm}$ using excitation wavelengths of $\lambda_{1}=368 \& \lambda_{2}=361 \mathrm{~nm}$. Fluorescence intensities are expressed in arbitrary units. Fluorescence titrations were carried out by adding increasing amounts of ctDNA directly into the cell containing solutions of ligands 1 and $\mathbf{2}$ ( $\mathrm{c}=20 \mu \mathrm{M}, 0.01 \mathrm{M}$ Tris- $\mathrm{HCl}, \mathrm{pH}=7.4)$. The concentration range of DNA for derivative $\mathbf{1}$ was 1-12 $\mu \mathrm{M}$ bp and $0-70 \mu \mathrm{M}$ bp for derivative 2. All measurements were performed at $24^{\circ} \mathrm{C}$.

2.3d Circular dichroism: CD spectra of complexes of ctDNA $\left(1.03 \times 10^{-3} \mathrm{M}\right.$ bp) with ligands $\mathbf{1}$ and $\mathbf{2}$ (28 $\mu \mathrm{M})$ were recorded $10 \mathrm{~min}$ after mixing on a J-810 Jasco spectropolarimeter at $24^{\circ} \mathrm{C}$. All measurements were performed in $0.01 \mathrm{M}$ Tris- $\mathrm{HCl}$ buffer $(\mathrm{pH}=7.4)$. A rectangular quartz cell with a $1 \mathrm{~cm}$ path length was used to obtain spectra from 200 to $350 \mathrm{~nm}$. The results are presented as a mean of three scans from which the buffer background was electronically subtracted.

2.3e Topoisomerase I relaxation assay: Calf thymus topoisomerase I (Takara, Japan) was used to determine topoisomerase I inhibition activity. pUC 19 DNA (1.4 $\mu \mathrm{g}$ ) was used as the substrate in a reaction volume of $20 \mu \mathrm{L}$ containing the reaction buffer and $0.1 \%$ bovine 
serum albumin. The tested inhibitors were added as indicated, and the reaction was initiated by the addition of 3 units of topoisomerase I. Reactions were carried out at $37^{\circ} \mathrm{C}$ for $45 \mathrm{~min}$.

2.3f Gel electrophoresis: Gel electrophoresis was performed at $7 \mathrm{~V} / \mathrm{cm}$ for $2 \mathrm{~h}$ in a TBE buffer on a $0.8 \%$ agarose gel. The gel was stained with ethidium bromide $(1 \mathrm{mg} / \mathrm{mL})$ and photographed under UV light.

2.3g Cell culture conditions: Mouse leukemia cell line L1210 and human ovarian carcinoma cell line A2780 were obtained from Dr. Ujhazy, Roswell Park Cancer Institute, Buffalo, USA. The cell lines were grown in a RPMI 1640 medium supplemented with $10 \% \mathrm{FBS}$, penicillin $(100 \mathrm{U} / \mathrm{mL})$, and streptomycin $(100 \mu \mathrm{g} / \mathrm{mL})$. The medium for the A2780 cell lines was also supplemented with $2 \mathrm{mM}$ glutamine. The cells were maintained at $37^{\circ} \mathrm{C}$ in a humidified $5 \% \mathrm{CO}_{2}$ atmosphere.

2.3h DCC: Cell proliferation, growth curves, and cytotoxic potential of compounds were determined using a trypan blue dye exclusion test (DCC). For the three-day experiments, cells were seeded $\left(1 \times 10^{5}\right.$ cells $/ \mathrm{mL}$ ) in Petri dishes and the tested substances (or $1 \%$ DMSO-control) were added after $24 \mathrm{~h}$. Cell proliferation was then checked after $24 \mathrm{~h}$ and $48 \mathrm{~h}$. All dye exclusion tests were performed in triplicate.

2.3i Intracellular accumulation of acridines 1 and 2 evaluated with fluorescence microscopy: The cells harvested in the log phase were counted and seeded $\left(0.5 \times 10^{6} / \mathrm{mL}\right)$. After $24 \mathrm{~h}$ incubation at $37^{\circ} \mathrm{C}$ in a humidified atmosphere of $5 \% \mathrm{CO}_{2}$ in air, acridines 1 and 2 were added for $2 \mathrm{~h}$, and the cells were then washed in PBS and observed using an optical microscope and a fluorescence microscope (Axio Zeiss Imager A1, camera AxioCam Mrc).

$2.3 \mathrm{j}$ Intracellular accumulation of acridine evaluated with HPLC: ODS columns were used for HPLC analysis of the acridine derivatives. The chromatographic separation of ester 2 was performed on a C18 column (Watrex, $250 \times 4$, Reprosil $100 \mathrm{C}_{18}$ with $5 \mu \mathrm{m}$ particle size) using a degassed mobile phase (a mixture of methanol and $50 \mathrm{mM}$ ammonium formate at a ratio of $80: 20(\mathrm{v} / \mathrm{v}), \mathrm{pH}$ adjusted to 4.5 with formic acid) at a flow rate of $0.5 \mathrm{~mL} / \mathrm{min}$. The column temperature was maintained at $25^{\circ} \mathrm{C}$ and the detection was carried out at $370 \mathrm{~nm}$. The standard concentration was 1 $\mathrm{nmol} / 20 \mu \mathrm{L}$ (the injection volume was $20 \mu \mathrm{L}$ ). The amount of derivative $\mathbf{2}$ in the cells was measured using methanol extraction and RP-HPLC analysis. The cell pellets were re-suspended in $100 \mu \mathrm{L}$ of methanol and mixed for $10 \mathrm{~min}$. The mixture was kept at $4^{\circ} \mathrm{C}$ for $1 \mathrm{~h}$. The tubes were then centrifuged at $6700 \mathrm{~g}$ for $15 \mathrm{~min}$ $\left(4^{\circ} \mathrm{C}\right)$ in order to produce pellets from the solid material and the extract $(20 \mu \mathrm{L})$ was injected into the HPLC system (LC-10AT pump, SPD-10Ai, UV-vis detector, Shimadzu, Japan).

2.3k HPLC analysis of GSH: GSH concentration was measured using Chen's method which utilizes the measurement of a GSH DTNB adduct (GSH-TNB; TNB-5-thionitrobenzoic acid) with HPLC. ${ }^{16}$ Cells (2 million A2780 cells detached by trypsinization) were washed with PBS three times before ice-cold methanol $(0.2 \mathrm{~mL})$ was added to the mixture of cells. The mixture was homogenized and centrifuged at $4000 \mathrm{rpm}$ for $15 \mathrm{~min}$ in order to remove the protein, the cell lysate supernatant $(50 \mu \mathrm{L})$ was vortex-mixed with a solution of $0.15 \mathrm{M}$ Tris- $\mathrm{HCl}(40 \mu \mathrm{L} ; \mathrm{pH}=7.5$, containing $1 \mathrm{mM}$ EDTA) and a solution of DTNB (10 mM, $10 \mu \mathrm{L})$ was added. The mixture was allowed to stand at room temperature for $15 \mathrm{~min}$ and subjected to HPLC analysis. The calibration solutions of GSH $(10-100 \mu \mathrm{M})$ were prepared by the reaction with DTNB in the same conditions as those of the cell lysate supernatant. HPLC analysis was carried out on a Shimadzu HPLC system (LC10AT pump, SPD-10Ai, UV-vis detector). An aliquot of $20 \mu \mathrm{L}$ of sample solution was injected (Rheodyne, $7725 i$ ) into a $\mathrm{C}_{18}$ column (Watrex, $250 \times 4$, Reprosil 100 $\mathrm{C}_{18}$ with $5 \mu \mathrm{m}$ particle size) and the mixed disulfide (of GSH with thionitrobenzoate) was eluted at a flow rate of $0.5 \mathrm{~mL} / \mathrm{min}$ with isocratic elution. Prior to analysis, the $\mathrm{C}_{18}$ column was pre-equilibrated for $30 \mathrm{~min}$ with a mobile phase consisting of methanol-ammonium formate $(23 \mathrm{mM}, \mathrm{pH}=5.8)(10: 90)$ at room temperature. The injection volume was $20 \mu \mathrm{L}$ and a wavelength of $356 \mathrm{~nm}$ was used for detection.

2.31 Fluorescence detection of superoxide: Fluorescence detection of superoxide dihydroethidium (DHE) was used to estimate intracellular superoxide production in the cells. ${ }^{17}$ Cells $\left(4 \times 10^{5}\right)$ in medium were incubated for $24 \mathrm{~h}$ at $37^{\circ} \mathrm{C}$, before derivatives $\mathbf{1}$ and $\mathbf{2}$ were added. The influence of the substances on the generation of free radicals was monitored after $1 \mathrm{~h}$. DHE (20 $\mu \mathrm{M}$ ) was added and incubated for $20 \mathrm{~min}$ at $37^{\circ} \mathrm{C}$. After incubation, the cells were washed in PBS and fluorescence was monitored with a fluorescence microscope (Axio Zeiss Imager A1, camera AxioCam Mrc). 


\section{Results and Discussion}

\subsection{Chemistry}

9-[(E)-2-Phenylethenyl]acridine (1) was prepared from benzyltriphenylphosphonium chloride which was first dehydrohalogenated with sodium hydride at low temperature to produce a corresponding yield as an orange suspension. ${ }^{18,19} 9$-acridinecarbaldehyde ${ }^{13}$ was added to this mixture thereby resulting in the formation of alkene 1 at a yield of $47 \%$ after $12 \mathrm{~h}$. The same carbaldehyde was transformed in a Wittig reaction in order to target methyl 3-(acridin-9-yl)-prop-2-enoate (2) with methyl (triphenylphosphoranylidene)acetate. ${ }^{20}$ The typically unsatisfactory yield from this reaction

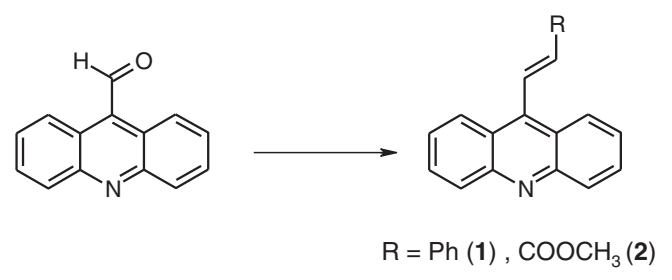

Scheme 1. Synthesis of acridin-9-ylalkenoic derivatives $\mathbf{1}$ and 2. Reagents and conditions: $\mathrm{Ph}_{3} \mathrm{P}^{+} \mathrm{CH}_{2} \mathrm{Ph} \mathrm{Cl}^{-}, \mathrm{NaH}$, THF, $-10^{\circ} \mathrm{C} \rightarrow \mathrm{rt}, 12 \mathrm{~h}$ and $\mathrm{Ph}_{3} \mathrm{P}=\mathrm{CHCOOCH}_{3}, \mathrm{CHCl}_{3}$, rt, $12 \mathrm{~h}$, resp. was improved through the use of a technique previously described by Märkl and $\mathrm{Merz}^{21}$ which requires neither a catalyst nor an anhydrous medium. In this way, the yield of alkene 2 was increased to $45 \%$ (scheme 1).

\subsection{Spectral and DNA binding studies}

The interaction of acridine compounds $\mathbf{1}, \mathbf{2}$, and $\mathbf{3}$ with calf thymus DNA (ctDNA) was monitored using spectrophotometric titrations in an aqueous buffer. The UVvis spectra showed significant absorption at the range of 300-450 nm, typical for transitions between electron energy levels of the acridine ring. ${ }^{22-24}$ Representative titrations are shown in figure 1 . In addition to the significant hypochromism of samples 1 and 2 (40$57 \%$ ), the smaller hypochromism of sample 3 (18\%), and a partial loss of the fine structure of the absorption bands, the absorption maxima of all DNA-ligand complexes exhibited very small bathochromic shifts of approximately $1 \mathrm{~nm}$ (sample $\mathbf{3}$ - $2 \mathrm{~nm}$ ) (table 1). The absence of tight isosbestic points in the titration experiments indicates that more than one type of DNA-ligand complex was formed. The values of hypochromism in this work (40-57\%) are comparable to those revealed in our previous work $(34-54 \%){ }^{25}$
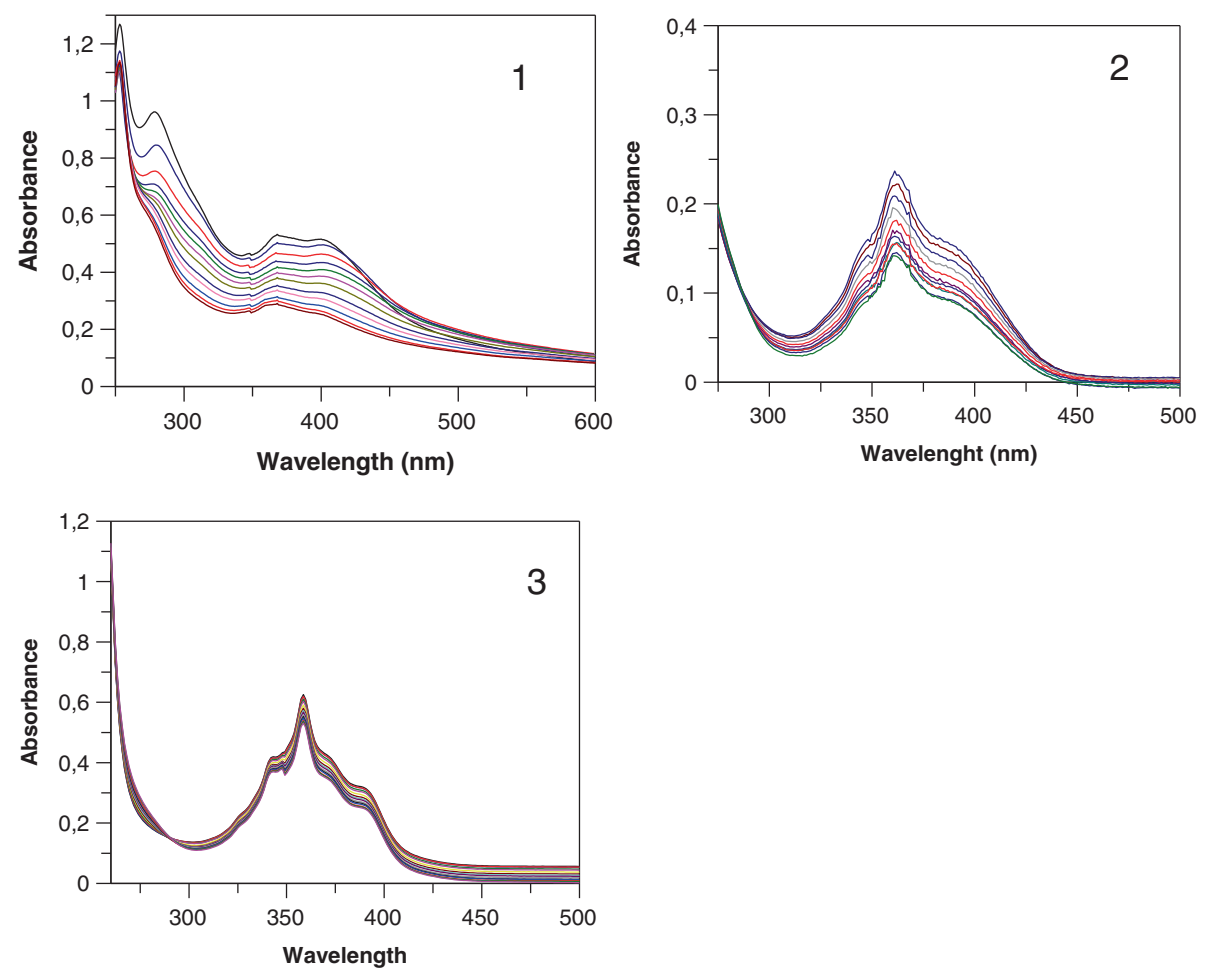

Figure 1. UV-vis spectrophotometric titration of 9-[(E)-2-phenylethenyl]acridine (compound1), acridine ester (compound 2), 3-\{[1-(acridin-9-yl)-3-methoxy-3oxopropyl]sulfanyl \}-2-aminopropanoic acid (compound 3), $25 \mu \mathrm{M}$ ) in $0.01 \mathrm{M}$ Tris$\mathrm{HCl}$ buffer $\left(\mathrm{pH}=7.4,24^{\circ} \mathrm{C}\right)$ at increasing concentrations of ctDNA (from top to bottom, 0-110 $\mu \mathrm{M}$ bp, at $10 \mu \mathrm{M}$ intervals). 
Table 2. Fluorescence data of acridine ligands $\mathbf{1}$ and $\mathbf{2}$ with ctDNA.

\begin{tabular}{lccc}
\hline Compound & $\lambda_{\text {ex }}$ & $\lambda_{\text {em }}$ & \\
\cline { 2 - 3 } & $(\mathbf{n m})$ & $(\mathbf{n m})$ & \\
\hline $\mathbf{1}$ & 368 & 526 & 1.0 \\
$\mathbf{2}$ & 361 & 500 & 0.95 \\
\hline
\end{tabular}

${ }^{a}$ Relative fluorescence intensity of free derivatives $(9.7 \mu \mathrm{M}$ in $0.01 \mathrm{M}$ Tris- $\mathrm{HCl}$ buffer, $\mathrm{pH}=7.4,24^{\circ} \mathrm{C}$ ).

UV-Vis titration data were then used in combination with McGhee and von Hippel plots in order to determine the binding constants of ligands $\mathbf{1}$ and $\mathbf{2}$ with ctDNA. ${ }^{14,15}$ The binding parameters obtained from the spectrophotometric analysis are summarized in table 1 . The binding constants determined by spectrophotometry were in the range of $1.9 \times 10^{5}-3.4 \times 10^{6} \mathrm{M}^{-1}$. The binding affinity values of the studied derivatives with calf thymus DNA are comparable with the $K$ values of other intercalators, e.g., acridine bis-imidazolinones $\left(1.9-7.1 \times 10^{5} \mathrm{M}^{-1}\right)$, daunomycin $\left(7.09 \times 10^{5} \mathrm{M}^{-1}\right)$, and acridine orange $\left(3.19 \times 10^{5} \mathrm{M}^{-1}\right){ }^{12}$
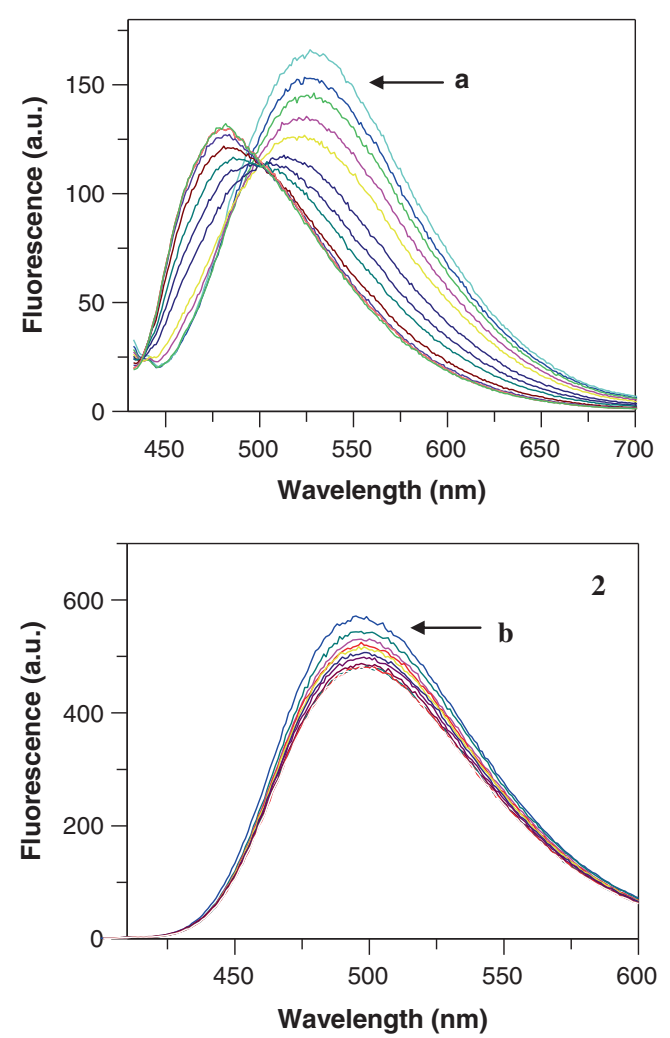

Figure 2. Spectrofluorimetric titration of 9-[(E)-2-phenylethenyl]acridine-compound $\mathbf{1}$ (a) and acridine ester - compound 2 (b) $(20 \mu \mathrm{M})$ in $0.01 \mathrm{M}$ Tris- $\mathrm{HCl}$ buffer $(\mathrm{pH}=7.4$, $24^{\circ} \mathrm{C}$ ) at increasing concentrations of ctDNA (from top to bottom, $0-12 \mu \mathrm{M}$ bp, at $1 \mu \mathrm{M}$ and $0-70 \mu \mathrm{M}$ bp, at $5 \mu \mathrm{M}$ intervals, respectively).

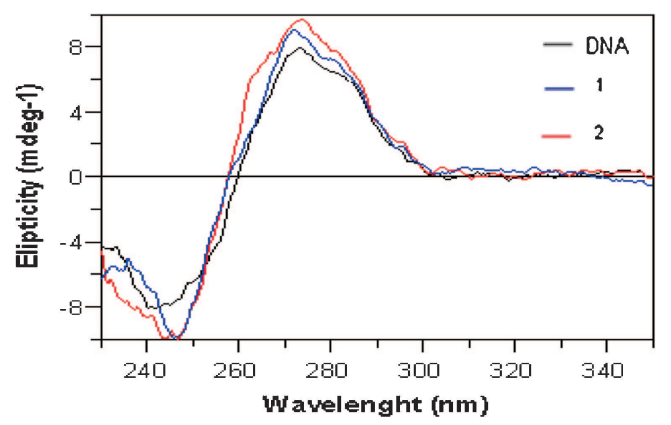

Figure 3. Circular dichroism spectra of ctDNA $(1.03 \times$ $10^{-4} \mathrm{M} \mathrm{bp}$ ) in both the presence and the absence of derivatives 1 and $2(28 \mu \mathrm{M})$ in $0.01 \mathrm{M}$ Tris- $\mathrm{HCl}$ buffer $(\mathrm{pH}=7.4$, $\left.24^{\circ} \mathrm{C}\right)$.

The spectrofluorimetric results show that the free acridine ligands $\mathbf{1}$ and $\mathbf{2}$ exhibited a distinct fluorescence (table 2). The binding of alkenes $\mathbf{1}$ and $\mathbf{2}$ with the DNA helix was corroborated by the significant reduction in fluorescence after consecutive additions of DNA to the ligand solution. This can be seen in figure 2 which shows the representative fluorescence spectra of $\mathbf{1}$ and 2 (figure 2).

Circular dichroism was used in order to monitor conformational changes after the addition of ligands $\mathbf{1}$ and $\mathbf{2}$ to DNA. The complexes produced a CD spectrum typical of B-form DNA with positive and negative Cotton effects at 278 and $245 \mathrm{~nm}$, respectively, (figure 3); these results are in accordance with previous biophysical studies of similar compounds. ${ }^{12}$ Changes to the negative bands showing non-significant red shifts were observed for both compounds. The positive band at $278 \mathrm{~nm}$ showed an increase of molar ellipticity and a mild red-shift of the band maxima in combination with an increase in intensity following the addition of compounds 1 and 2 to the DNA sample. These findings would suggest that the intercalation has stabilized the right-handed B-form of the DNA.

\subsection{Topoisomerase I relaxation assay}

Topoisomerases are essential DNA-targeting enzymes which induce DNA strand cleavage, a process which in turn leads to the reorganization and reconnection of the damaged DNA strand. The resultant relaxation of supercoiled DNA is necessary during the transcription or replication process. DNA intercalators have been shown to interfere significantly with this physiological process $;{ }^{26-31}$ the ligand that occupies the topoisomerase binding site can suppress the association of topoisomerase with DNA, thereby influencing topoisomerase activity. DNA intercalators which inhibit topoisomerase activity or which form stabilized ternary complexes 


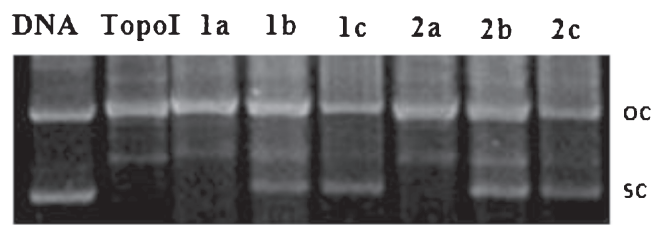

Figure 4. Inhibition of topoisomerase I-induced DNA relaxation by acridine ligands compound $\mathbf{1}$ and $\mathbf{2}$. Native supercoiled pUC $19(1.4 \mu \mathrm{g}$, lane DNA) was incubated for $45 \mathrm{~min}$ at $37^{\circ} \mathrm{C}$ with $3 \mathrm{U}$ of topoisomerase $\mathrm{I}$ in both the absence (lane TopoI) and presence of ligands (lane 1a, 2a - $5 \mu \mathrm{M}$, lane 1b, 2b - $30 \mu \mathrm{M}$, lane 1c, 2c - $60 \mu \mathrm{M})$. The DNA samples were run on agarose gel followed by ethidium bromide staining; sc - supercoiled plasmid, oc - open-circular plasmid.

with DNA and topoisomerase therefore show potential use in the development of DNA-targeting anticancer drugs. ${ }^{30}$

In order to study the effect of our ligands on the DNA relaxation, supercoiled plasmid pUC 19 was incubated with topoisomerase I in the presence of compounds 1 and 2 at concentrations of 5, 30 and $60 \mu \mathrm{M}$. As is shown in figure 4, the supercoiled DNA was fully relaxed by the enzyme in the absence of compounds 1 and 2 (line TopoI). Similarly, a greater proportion of the relaxed form of DNA was observed when ligands $\mathbf{1}$ and $\mathbf{2}$ were added at the lower concentration of $5 \mu \mathrm{M}$ (line 1a, 1b). However, as the concentration of ligands increased to 30 and $60 \mu \mathrm{M}$, the proportions of supercoiled plasmid form exceeded those of the relaxed form (lines $1 b, 2 b$ ). It is possible to suggest that this may be a result of topoisomerase I inhibition through a concurrent intercalation of ligands $\mathbf{1}$ and $\mathbf{2}$ into the topoisomerase binding site. It is also assumed that a ternary complex consisting of topoisomerase, DNA, and ligand could be stabilized significantly under these conditions.

\subsection{Effects of compounds $\mathbf{1}$ and $\mathbf{2}$ on mouse leukemia cell line L1210 and human ovarian carcinoma cells A2780}

The biological effects of acridine derivatives $\mathbf{1}$ and $\mathbf{2}$ were studied by analyzing changes in viability of L1210 and A2780 cancer cell lines in vitro.

3.4a Cytotoxicity of the 9-[(E)-2-phenylethenyl]acridine (1): 9-[(E)-2-phenylethenyl] acridine $\mathbf{1}$ showed a higher level of cytotoxicity towards A2780 cells than towards L1210 cells. While the compound suppressed the proliferation of the leukemic L1210 cells over the entire range of concentrations $(5-50 \mu \mathrm{M})$, the inhibition level was considerably higher at the highest concentration of $50 \mu \mathrm{M}$; the number of A2780 cells was reduced to approximately one third of the original number after $48 \mathrm{~h}$ (figure $\mathrm{S} 1$ ). The $\mathrm{IC}_{50}$ values $(48 \mathrm{~h}$ ) for L1210 and A2780 cells were $18.90 \mu \mathrm{M}$ and $5.45 \mu \mathrm{M}$, respectively.

The cells incubated with 9-[(E)-2-phenylethenyl] acridine $\mathbf{1}$ for $2 \mathrm{~h}$ had visibly accumulated this derivative. The microphotographs (figure 5) confirm that the compound was distributed differently in the A2780 and L1210 cells. Figure 6A shows that microgranules of $\mathbf{1}$ were formed in the L1210 cells.

3.4b Cytotoxicity of ester 2: The inhibitory effect of ester 2 on the proliferation of L1210 and A2780 cells was found to be even stronger than that of 9-[(E)2-phenylethenyl]acridine 1 (figure S2) and the A2780 cells were again seen to be more sensitive to compound 2 than the L1210 cells. A mild suppression of A2780 cells was observed the relatively low concentration of $5 \mu \mathrm{M}$ concentration, while the highest concentration of $50 \mu \mathrm{M}$ resulted in a rapid and strong inhibition after control

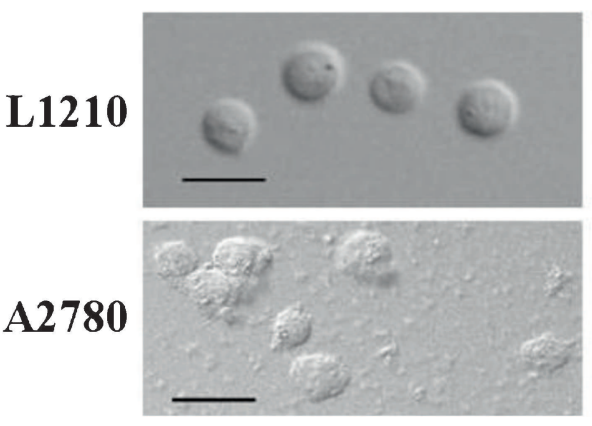

1

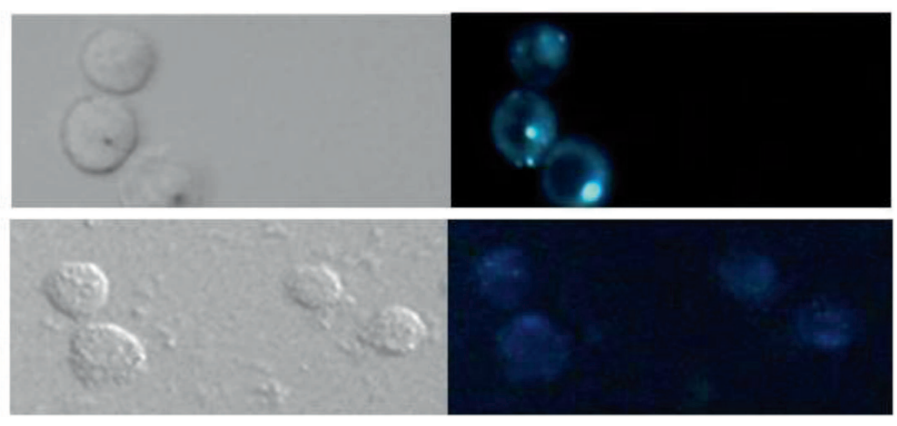

Figure 5. Intracellular uptake of 9-[(E)-2-phenylethenyl]acridine compound 1 in cells L1210 and A2780. Fluorescence of compound $1(50 \mu \mathrm{M})$ in the cells was monitored with a fluorescence microscope after $2 \mathrm{~h}$ incubation; magnification: $400 \times$, scale $20 \mu \mathrm{m}$. 
control

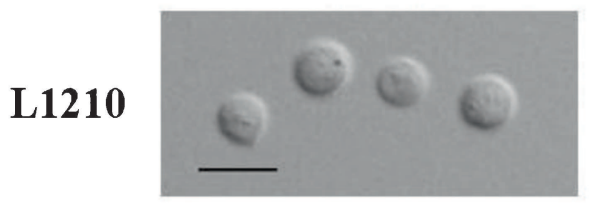

A2780

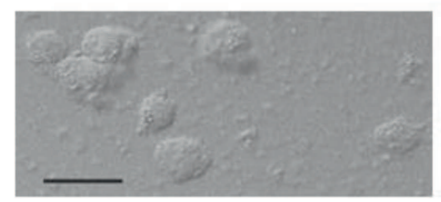

2

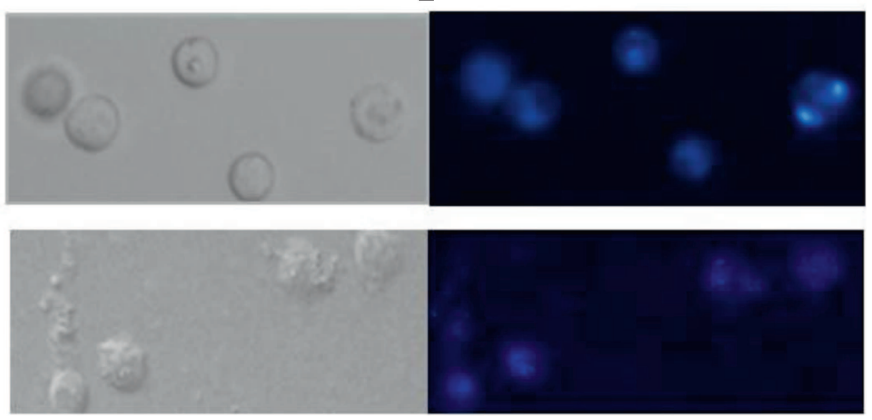

Figure 6. Intracellular uptake of ester 2 into L1210 and A2780 cells. The cells were incubated without (control) and with compound $2(50 \mu \mathrm{M})$ for $2 \mathrm{~h}$; magnification: $400 \times$, scale bar, $20 \mu \mathrm{m}$.

$24 \mathrm{~h}$ which also continued after $48 \mathrm{~h}$. The $\mathrm{IC}_{50}$ values (48 h) for L1210 and A2789 cells were $7.86 \mu \mathrm{M}$ and $4.60 \mu \mathrm{M}$, respectively.

The different levels of toxicity which ester 2 demonstrated against L1210 and A2780 cells could be associated with different levels of accumulation of ester $\mathbf{2}$ within these cell lines.

Microphotographs taken after incubation showed that compound $\mathbf{2}$ had accumulated in both types of cells. Compound $\mathbf{2}$ was not evenly localized in leukemic L1210 cells and that it was likely to be preferentially accumulated in the nucleus (figure 6). However, A2780 cells after incubation with derivative $\mathbf{2}$ showed a visible fluorescence in all cell structures.

\section{4c Changes of intracellular level of glutathione:} The acridin-9-ylalkenoic derivatives contain either deactivated alkene 1, and ester $\mathbf{2}$ includes the neighbouring ester group polarized $\mathrm{C}=\mathrm{C}$ double bond, therefore it would be expected that the studied compounds demonstrate reactivity towards nucleophilic HS-groupcontaining biomolecules including glutathione (GSH), the main intracellular low-molecular thiol. This form of interaction would also be expected to produce some new conjugated molecule(s) and change the level of glutathione in cells. Therefore the changes of GSH in the cells treated with ester $\mathbf{2}$ were examined and the concentration of the compound in the cells measured. After treatment with ester 2, a full depletion of GSH in L1210 cells and a 35\%-decrease of the GSH level in A2780 cells was observed following treatment with ester 2 (table 3). In contrast, no significant changes to the GSH levels of the cells were observed after the addition of 9-[(E)-2-phenylethenyl]acridine $\mathbf{1}$ practically (data not shown) and therefore its reactivity towards thiols was not studied.

The intracellular concentration of compound $\mathbf{2}$ was determined using HPLC analysis (figure S3). The cells were incubated with compound $2(15 \mu \mathrm{M})$ for $2 \mathrm{~h}$. It
Table 3. Levels of GSH in L1210 and A2780 cells after treatment with ester $\mathbf{2}$.

\begin{tabular}{lc}
\hline & nM GSH per $1 \times 10^{\mathbf{6}}$ cells \\
\hline $\mathrm{L} 1210$ control & $0.6 \pm 0.2$ \\
$\mathrm{~L} 1210+\mathbf{2}(15 \mu \mathrm{M})$ & 0 \\
$\mathrm{~A} 2780$ control & $2.0 \pm 0.2$ \\
$\mathrm{~A} 2780+\mathbf{2}(15 \mu \mathrm{M})$ & $1.3 \pm 0.1$ \\
\hline
\end{tabular}

is possible to suggest that ester $\mathbf{2}$ is present in the cells in a 'free' form or as a conjugate with glutathione (and other thiols, as well). Only cca. $1 \%$ of the 'free' form of ester 2 was found in cells. Thus it can be assumed that a conjugate of compound $\mathbf{2}$ with a reduced form of glutathione is the predominant form of conjugation in the cells.

As the depletion of intracellular glutathione can induce oxidative stress in cells, it was also possible to verify the presence of free radicals in the cells after incubation with compound 2 for $1 \mathrm{~h}$. As is shown in figure 7, the DHE assay confirmed the presence of strong oxidative stress in the cells along with a higher rate of free radical generation than was found in cells in the presence of menadione.

3.4d Interaction of conjugate 3-\{[1-(acridin-9-yl)-3methoxy-3-oxopropyl]sulfanyl\}-2-aminopropanoic acid with thiols: In order to examine the possible formation of conjugate(s) of ester $\mathbf{2}$ with thiols and to verify the cytotoxicity of these conjugates, a reaction product of compound $\mathbf{2}$ with $L$-cysteine was synthesized in methanol/Tris. $\mathrm{HCl}$ buffer $(2: 1)$ at room temperature in order to produce a precipitate of 3-\{[1-(acridin-9-yl)-3methoxy-3-oxopropyl]sulfanyl $\}$-2-aminopropanoic acid (3) which would be pure enough for spectroscopic identification. Because of its low solubility, 1D and 2D NMR analysis $\left({ }^{1} \mathrm{H},{ }^{13} \mathrm{C}\right.$, gCOSY, TOCSY, gHSQC, gHMBC, NOESY) was performed in DMSO- $\mathrm{D}_{6}$ and confirmed the structure of conjugate 3 as shown in scheme 2 . The 

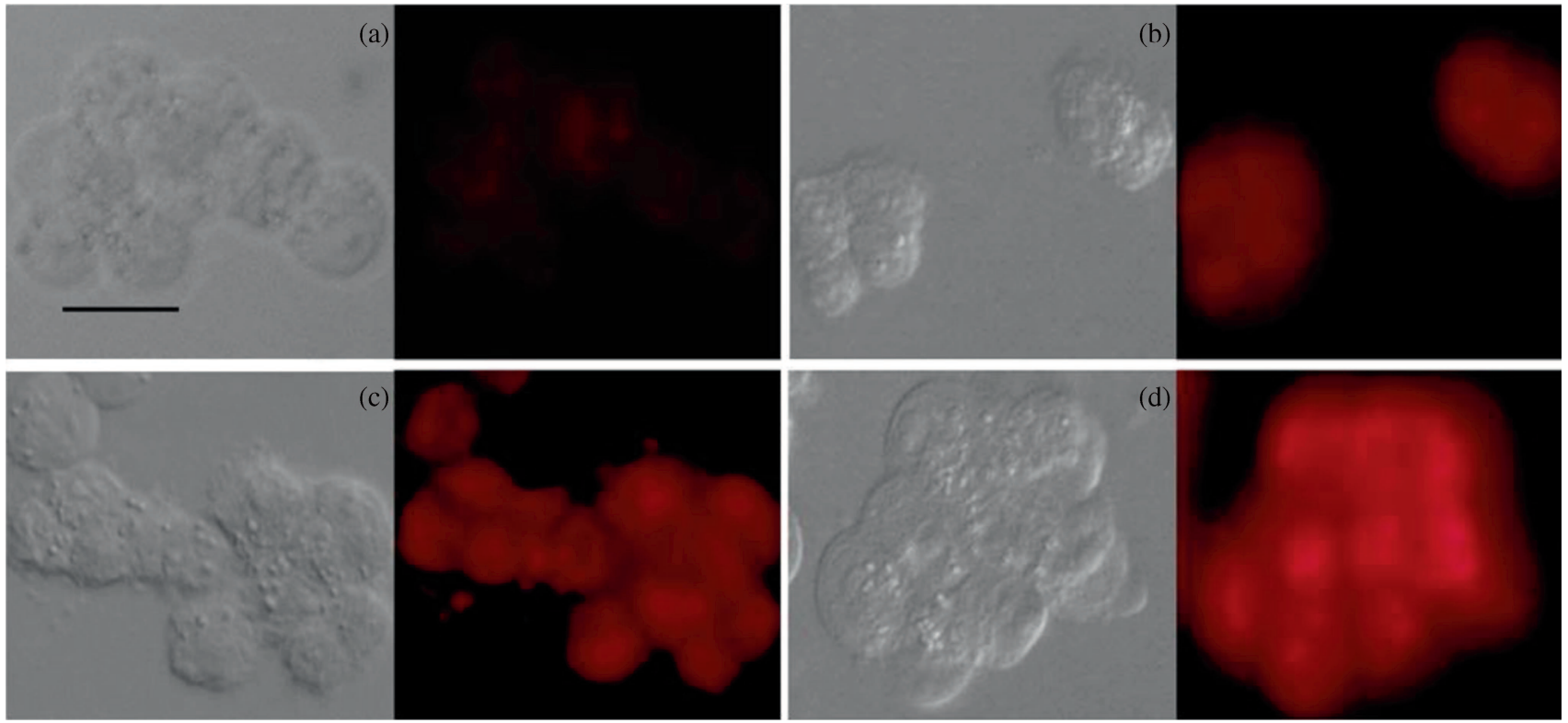

Figure 7. Oxidative stress in A2780 cells induced by compounds $\mathbf{1}$ and $\mathbf{2}$. The cells were incubated with compound $\mathbf{1}$ or $\mathbf{2}$ $(10 \mu \mathrm{M})$ for $1 \mathrm{~h}$ and oxidative stress was determined using a DHE assay. A - negative control, B - positive control (20 $\mu \mathrm{M}$ menadione), C-compound 2, D - compound 1 (magnification 400×); scale $20 \mu \mathrm{m}$.

results show that conjugate $\mathbf{3}$ had only limited stability in $\mathrm{DMSO}_{-} \mathrm{D}_{6}$ and underwent a slow partial decomposition into the starting compounds and some other decomposition/cyclization product over the course of a few hours.

The creation of the GSH-xenobiotics conjugate acts as a method of detoxifying the xenobiotic drug, and therefore we decided to compare the cytotoxicity of compound $\mathbf{3}$ with that of the pure ester $\mathbf{2}$. As can be seen in figure $\mathrm{S} 4$, conjugate $\mathbf{3}$ is less cytotoxic than the pure ester 2, especially at concentrations higher than $10 \mu \mathrm{M}$. Although the reaction of compound $\mathbf{2}$ with thiol did not eliminate its cytotoxicity entirely, a trend toward diminishing it was noted after the formation of the conjugate. These results suggest that the double $\mathrm{CH}=\mathrm{CH}$ bond and the methyl ester group in ester $\mathbf{2}$ conjugated at opposite sides of the acridine ring, thereby enhancing the cytotoxic properties of the acridine skeleton. The saturation of this double bond into a single $\mathrm{C}-\mathrm{C}$ bond which interrupts extended electron conjugation within compound $\mathbf{3}$ may be seen as one possible reason for the decrease in the originally considerable cytotoxicity of the studied acridinyl-alkenoic compounds. The reduced cytotoxicity of 9-[(E)-2-phenylethenyl]acridine 1 towards both cell lines may be due to a series of factors such as the less polar character of the compound, higher hydrophobicity, increased volume, lower flexibility, and also the expected coplanarity of the acridine and phenyl substituents at the double bond. All these factors can contribute to the reduced ability of compound $\mathbf{1}$ to penetrate the intracellular membranes and incorporate itself into the nucleus.<smiles>COC(=O)/C=C/c1c2ccccc2nc2ccccc12</smiles><smiles>COC(=O)C[C@@H](SC[C@H](N)C(=O)O)c1c2ccccc2nc2ccccc12</smiles>

Scheme 2. Synthesis of conjugate 3-\{[1-(acridin-9-yl)-3-methoxy-3-oxopropyl]sulfanyl $\}$-2-aminopropanoic acid (3). 


\section{Conclusions}

Our studies show that ester $\mathbf{2}$ demonstrates a stronger cytostatic effect on leukemia cell line L1210 than 9-[(E)-2-phenylethenyl]acridine 1. The incubation of compounds $\mathbf{1}$ and $\mathbf{2}$ with ovarian carcinoma cell line A2780 showed extensive cytotoxic effects which were especially marked in the case of compound 2 . The mechanism of the cytotoxicity of studied acridine derivatives can be related to their affinity towards DNA and their capability to inhibit topoisomerase I. An additional factor may be the different characters of compounds 1 and 2; the former is more hydrophobic, more bulky and less flexible, whereas the latter is more polar and flexible during transportation through intracellular membranes and more reactive towards nucleophilic low-weight cell metabolites. In addition, compounds 1 and 2 are both able to induce oxidative stress in cells. The fact that ester $\mathbf{2}$ shows a higher reactivity towards thiols than 9-[(E)-2-phenylethenyl]acridine 1 can be taken as further proof of the crucial role of polarity in the interaction of the studied molecules with detoxification agents such as glutathione or cysteine.

\section{Supplementary Information}

Figures S1 to S4 are provided in the supplementary information and is available at www.ias.ac.in/chemsci.

\section{Acknowledgement}

This study was supported by Slovak Research and Development Agency VEGA grants 1/0001/13 and 1/0790/14.

\section{References}

1. Lang X, Li L, Chen Y, Sun Q, Wu Q, Liu F, Tan C, Liu $\mathrm{H}, \mathrm{Gao} \mathrm{C}$ and Jiang Y 2013 Bioorg. Med. Chem. 214170

2. Chaires J B 1998 Curr. Opin. Struct. Biol. 8314

3. Graves D E and Velea L M 2000 Curr. Org. Chem. 4 915

4. Ihmels H and Otto D 2005 Top. Curr. Chem. 258 161

5. Vantova Z, Paulikova H, Sabolova D, Kozurkova M, Suchanova M, Janovec L, Kristian P and Imrich J 2009 Int. J. Biol. Macromol. 45174

6. Lord C J and Ashworth A 2012 Nature 481287
7. Plsikova J, Janovec L, Koval J, Ungvarsky J, Mikes J, Jendzelovsky R, Fedorocko P, Imrich J, Kristian P, Kasparkova J, Brabec V and Kozurkova M 2012 Eur. J. Med. Chem. $\mathbf{5 7} 283$

8. Su T L, Lin Y-W, Chou T-C, Zhang X, Bacherikov V A, Chen C-H, Liu L F and Tsai T-J 2006 J. Med. Chem. 49 3710

9. Schafer F Q and Buettner G R 2001 Free Radic. Biol. Med. 301191

10. Go Y M and Jones D P 2010 Antioxid. Redox Signal. 13 489

11. Kern J C and Kehrer J P 2005 Front. Biosci. 101727

12. Paulikova H, Vantova Z, Hunakova L, Cizekova L, Carna M, Kozurkova M, Sabolova D, Kristian P, Hamulakova S and Imrich 2012 J. Bioorg. Med. Chem. 207139

13. Bedlovicova Z, Imrich J, Kristian P, Danihel I, Sabolova D, Kozurkova M, Böhm S, Paulikova H and Klika KD 2010 Heterocycles 801047

14. McGhee J D and von Hippel P H 1974 J. Mol. Biol. 86 469

15. Busa J, Octave TechnicalUniversity in Kosice, Kosice 2006

16. Chen W, Zhao Y, Seefeldt T and Guan X 2008 J. Pharm. Biomed. Anal. 481375

17. Zhao H, Joseph J, Fales H M, Sokoloski E A, Levine R L, Vasquez-Vivar J and Kalyanaraman B 2005 Proc. Natl. Acad. Sci. U.S.A. 1025727

18. Vedejs E, Marth C F and Ruggeri R 1988 J. Am. Chem. Soc. 1103940

19. Vedejs E and Marth C F 1988 J. Am. Chem. Soc. 110 3948

20. Vlassa M, Molnariu C and Silberg J A 1994 Rev. Roum. Chemie 39315

21. Märkl G and Merz A 1973 Synthesis 295

22. Carlson C B and Beal P A 2000 Bioorg. Med. Chem. Lett. 101979

23. Delcros J G, Tomasi S, Carrington S, Martin B, Renault J, Blagbrough I S and Uriac P 2002 J. Med. Chem. 45 5098

24. Baranovsky S F, Bolotin P A, Evstigneev M P and Chenyshev D N 2009 J. Appl. Spectrosc. 76132

25. Janovec L, Kozurkova M, Sabolova D, Ungvarsky J, Paulikova H, Plsikova J, Vantova Z and Imrich J 2011 Bioorg. Med. Chem. 191790

26. Pommier Y 2006 Nat. Rev. Cancer 6789

27. Chaudhuri P, Majumder H K and Bhattacharya S 2007 J. Med. Chem. $\mathbf{5 0} 2536$

28. Leppard J B and Champoux J J 2005 Chromosoma 114 75

29. McClendon A K and Osheroff N 2007 Mutat. Res. 623 83

30. Kathiravan M K, Khilare M M, Nikoomanesh K, Chothe A S and Jain K S 2013 J. Enz. Inhib. Med. Chem. 28419

31. Basili S, Basso G, Faccio A, Granzhan A, Ihmels H, Moro S and Viola G 2008 Chem. Med. Chem. 31671 